\title{
Pengaruh Profesionalisme Guru Terhadap Hasil Belajar \\ Peserta Didik Pada Mata Pelajaran Bahasa Arab \\ Di Madrasah Tsanawiyah Negeri Model Palu
}

\author{
Nursyam, Jafar Sidik \\ Institut Agama Islam Negeri Palu, Indonesia \\ Jl. Diponegoro No. 23, Kec: Palu Barat, Kota Palu, Sulawesi Tengah, 94221, Indonesia \\ Corresponding E-mail: @jeimshin23@gmail.com
}

\begin{abstract}
Abstrack
The research aims to determine the influence of teacher professionalism towards student learning outcomes on Arabic lesson at State Islamic Junior High School of Palu. It is quantitative research, which is the author uses method by taking 90 samples. Data collection was carried out using questionnaires, observation, documentation and interviews. Instrument analysis includes validity and reliability tests. The data analysis used is simple linear regression correlation analysis. The result is the influence of teachers' professionalism towards student learning outcomes on Arabic lesson at State Islamic Junior High School of Palu was $40.1 \%$ and $59.9 \%$ were influenced by other factors which is exclude of the research.
\end{abstract}

Keywords : Teachers' Professionalism, Student learning outcomes

\begin{abstract}
Abstrak
Penelitian ini bertujuan untuk mengetahui adanya pengaruh profesionalisme guru terhadap hasil belajar peserta didik pada mata pelajaran bahasa Arab di Madrasah Tsanawiyah Negeri Model Palu. Penelitian ini merupakan penelitian kuantitatif dengan mengambil sampel sebanyak 90 peserta didik. Pengumpulan data dilakukan dengan menggunakan metode angket, observasi, dokumentasi dan wawancara. Analisis instrument meliputi uji validitas dan reliabilitas. Analisis data yang digunakan adalah analisis korelasi regresi linear sederhana. Hasil penelitian menunjukkan bahwa terdapat pengaruh signifikan antara variabel profesionalisme guru terhadap variabel hasil belajar Peserta didik pada mata pelajaran bahasa Arab di Madrasah Tsanawiyah Negeri Model Palu. Adapun besar tingkat pengaruh profesionalisme guru terhadap hasil belajar peserta didik di Madrasah Tsanawiyah Negeri Model Palu ditemukan bahwa sebesar $40.1 \%$ sedangkan sisanya sebesar 59.9\% dipengaruhi faktor-faktor lain yang tidak dimasukkan dalam penelitian ini.
\end{abstract}

Kata Kunci : Profesionalisme Guru, Hasil belajar bahasa Arab

\section{Pendahuluan}

Saat ini, Indonesia membutuhkan orang-orang yang dapat berfikir secara efektif, efisien dan juga produktif. Hal tersebut dapat diwujudkan jika kita mempunyai tenaga pendidik yang handal dan mampu mencetak generasi bangsa yang pintar dan bermoral.
Guru merupakan orang yang sangat berpengaruh dalam proses belajar mengajar. Hasil belajar yang diperoleh peserta didik dipengaruhi oleh cara guru dalam pelaksanaan pembelajaran. Guru yang profesional adalah seorang guru yang memiliki kualifikasi akademik, kompetensi, sehat jasmani dan rohani, serta memiliki kemampuan untuk 
mewujudkan tujuan pendidikan nasional yang disertai dengan peningkatan kesejahteraan yang layak. Profesionalisme seorang guru menjadi suatu keharusan dalam mewujudkan sekolah yang berbasis pengetahuan, yaitu pemahaman tentang pembelajaran, kurikulum dan perkembangan manusia termasuk gaya belajar. ${ }^{1}$

Guru merupakan komponen manusiawi dalam proses belajar mengajar yang sangat berperan dalam mengantarkan peserta didiknya pada tujuan pendidikan yang telah ditentukan. Gurulah yang memikul tanggung jawab atas keberhasilan dan kegagalannya program pengajaran. Oleh karena itu mengajar merupakan pekerjaan profesional, karena itu menggunakan teknik dan prosedur yang berpijak pada landasan intelektual yang harus dipelajari secara sengaja, terencana dan kemudian dipergunakan demi kemaslahatan orang lain.

Ada beberapa kriteria pokok pekerjaan yang bersifat profesional sehubungan dengan profesionalisme seseorang, Nana Sudjana memberikan kriteria sebagai berikut: "Bahwa pekerjaan itu dipersiapkan melalui proses pendidikan dan latihan, mendapat pengakuan dari masyarakat, adanya organisasi profesi,

${ }^{1}$ Hamzah B. Uno, Profesi Kependidikan, (Jakarta: PT Bumi Aksara, 2012), h. 18. mempunyai kode etik".2

Secara jujur diakui bahwa pembelajaran Bahasa Arab pada tingkat Madrasah Tsanawiyah khususnya Madrasah Tsanawiyah Negeri Model Palu telah menunjukkan peningkatan hasil belajar peserta didik yang baik dari tahun ke tahun sehingga dapat dikatakan bahwa pembelajaran Bahasa Arab di Madrasah Tsanawiyah Negeri Model Palu telah sesuai harapan sebagaimana yang diamanatkan dalam tujuan pembelajaran Bahasa Arab dalam Permenag RI nomor 2 tahun 2008 tentang Standar Kompetensi Lulusan dan Standar Isi Pendidikan Agama Islam dan Bahasa Arab di Madrasah.

Namun harapan untuk dapat lebih meningkatkan hasil belajar Bahasa Arab peserta didik di Madrasah Tsanawiyah Negeri Model Palu itu cukup besar, setidak-tidaknya karena dua alasan; Pertama, $75 \%$ peserta didik berasal dari satuan pendidikan Madrasah Ibtidaiyah sehingga Bahasa Arab bukanlah hal yang asing bagi mereka. Kedua, hampir seluruh peserta didik telah mengenyam pendidikan baca Al-Qur'an di lembaga pendidikan non formal, seperti TPQ, Madrasah Diniyah atau mengaji di Mushalah, di Masjid dan tinggal di Asrama Pesantren.

Berangkat dari fenomena yang telah dipaparkan secara singkat di atas,

2 Nana Sudjana, Dasar-Dasar Proses Belajar Mengajar, (Bandung: Sinar Baru Algensindo, 2000), h. 14 
maka penulis tertarik dan memandang perlu untuk mengadakan penelitian dalam rangka mengkaji apakah guru profesional yang dimiliki oleh Madrasah Tsanawiyah Negeri Model Palu memiliki pengaruh dalam meningkatnya hasil belajar bahasa Arab peserta didik?

\section{Profesionalisme Guru}

Guru merupakan suatu profesi, yang berarti suatu jabatan yang memerlukan keahlian khusus sebagai guru dan tidak dapat dilakukan oleh sembarang orang di luar bidang pendidikan.

\section{Dalam UU Negara Republik} Indonesia Nomor 14 Tahun 2005 tentang guru dan dosen dalam pasal 2 ayat 1 dijelaskan bahwa: "Guru mempunyai kedudukan sebagai tenaga profesional pada jenjang pendidikan dasar, pendidikan menengah, dan pendidikan anak usia dini pada jalur pendidikan formal yang diangkat sesuai dengan peraturan perundang-undangan"3. Guru sebagai tenaga profesional mengandung arti bahwa pekerjaan guru hanya dapat dilakukan oleh seseorang yang mempunyai kualifikasi akademik, kompetensi, dan sertifikat pendidik sesuai dengan persyaratan untuk setiap jenis dan jenjang pendidikan tertentu.

Secara etimologi profesi berasal dari kata profession yang berarti pekerjaan.

\footnotetext{
${ }^{3}$ Ibid., h. 96
}

Profesional artinya orang yang ahli atau tenaga ahli. Professionalism artinya sifat profesional.4 Dalam Kamus Besar Bahasa Indonesia (KBBI), istilah profesionalisasi, ditemukan sebagai berikut: profesi adalah bidang pekerjaan yang dilandasi pendidikan keahlian (keterampilan, kejuruan, dan sebagainya) tertentu. Profesional adalah (1) bersangkutan dengan profesi, (2) memerlukan kepandaian khusus untuk menjalankannya, dan (3) mengharuskan adanya pembayaran untuk melakukannya. Profesionalisme adalah mutu, kualitas, dan tindak tanduk yang merupakan ciri suatu profesi atau orang yang profesional. ${ }^{5}$

Kata profesi menunjuk pada suatu pekerjaan yang menuntut keahlian, tanggung jawab dan kesetiaan pada profesi. Suatu profesi secara teori tidak dapat dilakukan oleh sembarang orang yang tidak dilatih atau tidak memiliki keahlian khusus. Berbicara mengenai kata profesi, ada beberapa istilah yang berkaitan, yaitu profesi, profesional, profesionalisme, profesionalisasi dan profesionalitas.

Menurut Sanusi dkk yang dikutip oleh Ali Mudlofir menjelaskan kelima konsep tersebut sebagai berikut:

3 John M. Echols dan Hasan Shadily, Kamus Inggris Indonesia, (Jakarta: Gramedia, 1990), h. 449.

5 Pusat Bahasa Departemen Pendidikan Nasional., Kamus Besar Bahasa Indonesia edisi III. Cet. I; (Jakarta: Balai Pustaka, 2001), h. 897. 
a. Profesi adalah suatu jabatan atau pekerjaan yang menuntut keahlian (expertise) dari pada anggotanya. Artinya, ia tidak bisa dilakukan oleh sembarangan orang yang tidak dilatih dan tidak disiapkan secara khusus untuk melakukan pekerjaan itu. Keahlian diperoleh melalui apa yang disebut profesionalisasi, yang dilakukan baik sebelum seseorang menjalani profesi itu (pendidikan/latihan prajabatan) maupun setelah menjalani suatu profesi (in-service training). Diluar pengertian ini, ada beberapa ciri profesi khususnya yang berkaitan dengan profesi kependidikan.

b. Profesional menunjuk pada dua hal. Pertama, orang yang menyandang suatu profesi, misalnya"Dia seorang profesional”. Kedua, penampilan seseorang dalam melakukan perkerjaannya yang sesuai dengan profesinya. Pengertian kedua ini, profesional dikontraskan dengan "nonprofesional" atau "amatir".

c. Profesionalisme menunjuk pada komitmen/teori/paham para anggota suatu profesi untuk meningkatkan kemampuan profesionalnya dan terus-menerus mengembangkan strategi-strategi yang digunakannya dalam melakukan pekerjaan yang sesuai dengan profesinya.

d. Profesinalitas mengacu kepada sikap para anggota profesi terhadap profesinya serta derajat pengetahuan dan keahlian yang mereka miliki dalam rangka melakukan pekerjaannya.

e. Profesionalisasi menunjuk pada proses peningkatan kualifikasi maupun kemampuan para anggota profesi dalam mencapai kriteria yang standar dalam penampilannnya sebagai anggota suatu profesi. Profesionalisasi pada dasarnya merupakan serangkaian proses pengembangan profesional (professional development) baik dilakukan melalui pendidikan/latihan "prajabatan" maupun “dalam-jabatan”. Oleh karena itu, profesionalisasi merupakan proses yang life-long dan never-ending, secepat seseorang telah menyatakan dirinya sebagai warga suatu profesi. ${ }^{6}$

Profesional menunjuk pada penampilan seseorang yang sesuai dengan tuntutan yang sesuai dengan profesinya atau bisa juga menunjuk pada orangnya. Profesionalisasi menunjuk pada cara bagaimana seseorang menjadi profesional

6 Ali Mudlofir, Pendidik Profesional, (Jakarta: PT Raja Grafindo Persada, 2012), h. 19. 
melalui pendidikan yang dilakukannya. Proses ini dapat belangsung lama, baik sebelum pra jabatan maupun dalam masa jabatan. Sedangkan profesionalisme menunjuk kepada komitmen anggota profesi untuk bekerja berdasarkan standar yang tinggi dan kode etik profesinya.

Pada umumnya masyarakat awam memaknai kata profesionalisme bukan hanya digunakan untuk pekerjaan yang telah diakui sebagai suatu profesi, melainkan hampir setiap pekerjaan. Muncul ungkapan misalnya penjahat profesional, sopir profesional, hingga tukang ojek profesional. Dalam bahasa awam pula, seseorang disebut profesional jika cara kerjanya baik, cekatan, dan hasilnya memuaskan. Dengan hasil kerjanya itu, seseorang mendapatkan uang atau dalam bentuk imbalan lainnya.

Sudarwan Danim merujuk pendapat Howard M. Volmmer dan Donald. L Mills berpendapat bahwa "profesi adalah suatu pekerjaan yang menuntut kemampuan intelektual khusus yang diperoleh melalui kegiatan belajar dan pelatihan yang bertujuan untuk menguasai keterampilan atau keahlian dalam melayani atau memberikan advis pada orang lain dengan memperoleh upah atau gaji dalam jumlah tertentu". ${ }^{7}$

7 Sudarwan Danim, Profesionalisasi dan Etika Profesi Guru; (Bandung: Alfabeta, 2013), h. 56.
Profesional menurut rumusan Undang-undang Nomor 14 Tahun 2005 Bab I Pasal 1 ayat 4 digambarkan sebagai "pekerjaan atau kegiatan yang dilakukan oleh seseorang dan menjadi sumber penghasilan kehidupan yang memerlukan keahlian, kemahiran dan kecakapan yang memenuhi standar mutu dan norma tertentu serta memerlukan pendidikan profesi". 8

Dari berbagai pengertian di atas tersirat bahwa dalam profesi digunakan teknik dan prosedur intelektual yang harus dipelajari secara sengaja, sehingga dapat diterapkan untuk kemaslahatan orang lain. Sedangkan profesionalisme pada dasarnya berasal dari kata profesi yang berarti suatu pekerjaan yang memiliki tanda dengan terkait ketrampilan yang lihai/intelektual. dengan kata lain profesionalisme merupakan suatu paham yang mengajarkan bahwa segala sesuatu pekerjaan harus dilandasi dengan keahlian tertentu dan ditempuh dengan cara bekerja sesuai standar dan kode etik profesinya.

Undang-Undang Dasar Nomor 14 Tahun 2005 tentang Guru dan Dosen dalam pasal 1 ayat 1 merumuskan pengertian guru : "Guru adalah pendidik profesional dengan tugas utama mendidik, mengajar, membimbing, mengarahkan, melatih, menilai, dan mengevaluasi peserta

8 Abd. Rahman Getteng, Menuju Guru Profesional dan Beretika; (Yogyakarta: Graha Guru, 2011), h. 93. 
didik pada pendidikan anak usia dini jalur pendidikan formal, pendidikan dasar, dan pendidikan menengah". 9

Pengertian Guru di atas memberikan ketegasan bahwa guru merupakan pendidik yang profesional dan memiliki 7 (tujuh) tugas utama yaitu, (1) mendidik peserta didik, (2) mengajar peserta didik, (3) membimbing peserta didik, (4) mengarahkan peserta didik, (5) melatih peserta didik, (6) menilai peserta didik, dan (7) mengevaluasi peserta didik.

Guru adalah jabatan atau profesi yang membutuhkan keahlian khusus. Pekerjaan sebagai guru ini tidak bisa dilakukan oleh seseorang tanpa mempunyai keahlian sebagai guru. Menjadi seorang guru dibutuhkan syaratsyarat khusus. Apa lagi jika menjadi seorang guru yang profesional maka harus menguasai seluk beluk pendidikan serta mengajar dengan berbagai ilmu pengetahuan lainnya yang harus dikembangkan melalui masa pendidikan tertentu.

Pengertian dan definisi guru adalah sebagai pengelola kegiatan proses pembelajaran di mana dalam hal ini guru bertugas untuk mengarahkan kegiatan pembelajaran peserta didik agar dapat mencapai tujuan pembelajaran. Dalam hal ini, guru juga merupakan unsur penting dalam bidang pendidikan. Karena itu

\footnotetext{
${ }^{9}$ Ibid, h. 96
}

peranan guru khususnya guru profesional dalam meningkatkan mutu dan kualitas peserta didik harus diperhitungkan dengan sungguh-sungguh.

Profesionalisme guru adalah suatu tingkat penampilan seseorang dalam melaksanakan pekerjaan sebagai guru yang didukung dengan keterampilan dan kode etik. $^{10}$ Profesionalisme guru adalah kemampuan guru untuk melakukan tugas pokoknya sebagai pendidik dan pengajar meliputi kemampuan merencanakan, melakukan, dan melaksanakan evaluasi serta menjunjung tinggi kode etik yang sesuai dengan profesinya.

\section{Hasil Belajar Peserta Didik}

Belajar merupakan proses perubahan tingkah laku yang berlangsung dalam jangka waktu tertentu melalui pemberian pengetahuan, latihan maupun pengalaman. Menurut Sardiman bahwa "Belajar adalah suatu proses yang kompleks yang terjadi pada semua orang dan berlangsung seumur hidup, sejak masih bayi hingga ke- liang lahat". ${ }^{11}$

Sedangkan menurut Slameto "Belajar adalah suatu proses usaha yang dilakukan sesorang untuk memperoleh suatu perubahan tingkah laku yang baru secara keseluruhan sebagai hasil

${ }^{10}$ Abu Bakar Yunus dan Syarifan Nurjan, Profesi Keguruan, (Surabaya: A Print, 2009), h. 2.

11 Sardiman, Media Pendidikan, (Jakarta: Raja Grafindo Persada, 2002), h. 1. 
pengalamannya sendiri dalam interaksi dengan lingkungannya". ${ }^{12}$

Setiap individu pasti mengalami proses belajar. Belajar dapat dilakukan oleh siapapun, baik anak-anak, remaja, orang dewasa maupun orangtua, dan akan berlangsung seumur hidup. Dalam pendidikan di sekolah belajar merupakan kegiatan pokok yang harus dilaksanakan. Tujuan pendidikan akan tercapai apabila proses belajar dalam suatu sekolah dapat berlangsung dengan baik, yaitu proses belajar yang melibatkan peserta didik secara aktif dalam proses pembelajaran.

Hasil belajar merupakan hal yang berhubungan dengan kegiatan belajar karena kegiatan belajar merupakan proses sedangkan hasil belajar adalah sebagai hasil yang dicapai seseorang setelah mengalami proses belajar dengan terlebih dahulu mengadakan evaluasi dari proses belajar yang dilakukan. Untuk memahami pengertian hasil belajar maka harus bertitik tolak dari pengertian belajar itu sendiri.

Sudjana mengemukakan bahwa "hasil belajar adalah kemampuan yang dimiliki siswa setelah menerima pengalaman belajar". ${ }^{13}$ Selanjutnya, Oemar Hamalik, menjelaskan bahwa "hasil belajar adalah pola-pola perbuatan, nilai-nilai,

12 Slameto, Belajar dan Faktor-Faktor yang Mempengaruhinya, (Jakarta: Rineka Cipta, 2003), h. 2.

13 Nana Sudjana, Penilaian Hasil Proses Belajar Mengajar, (Bandung: PT. Remaja Rosdakarya, 1991), h. 22. pengertian, sikap apresiasi, kapabilitas, dan keterampilan."14

Kusnandar mengemukakan bahwa "hasil belajar adalah kemampuan siswa dalam memenuhi suatu tahapan pencapaian pengalaman belajar dalam satu kompetensi dasar". ${ }^{15}$

Hasil belajar merupakan tujuan akhir dilaksanakannya kegiatan pembelajaran di sekolah. Hasil belajar dapat ditingkatkan melalui usaha sadar yang dilakukan secara sistematis mengarah kepada perubahan yang positif yang kemudian disebut proses belajar. Hasil belajar dapat dikatakan tuntas apabila telah memenuhi kriteria ketuntasan minimum yang ditetapkan oleh masing-masing guru mata pelajaran.

Hasil belajar sering dipergunakan dalam arti yang sangat luas yakni untuk bermacam-macam aturan terdapat apa yang telah dicapai oleh murid, misalnya ulangan harian, tugas-tugas pekerjaan rumah, tes lisan yang dilakukan selama pelajaran berlangsung, tes akhir dan sebagainya. Hasil belajar bisa berbentuk pengetahuan, keterampilan, maupun sikap.

Berdasarkan pengertian tersebut, hasil belajar dapat disimpulkan sebagai perubahan perilaku positif serta

14 Oemar Hamalik, Proses Belajar Mengajar, (Jakart: PT. Bumi Aksara, 2006), h. 39.

$\begin{array}{rrr}15 & \text { Kusnandar, Guru Profesional } \\ \text { Implementasi Kurikulum Tingkat Satuan }\end{array}$ Pendidikan (KTSP) dan Persiapan Menghadapi Sertifikasi Guru, (Jakarta: PT. Raja Grafindo Persada, 2007), h. 229. 
kemampuan yang dimiliki peserta didik dari suatu interaksi belajar mengajar. Hasil belajar yang dapat diperoleh hasil belajar kognitif, afektif, dan psikomotorik. Perubahan tersebut dapat diartikan terjadinya peningkatan dan pengembangan yang lebih baik dibandingkan sebelumnya.

Banyak faktor yang dapat mempengaruhi hasil pembelajaran. Ada faktor yang dapat diubah, adapula faktor yang harus diterima apa adanya. Adapun Menurut Slameto, faktor-faktor yang mempengaruhi hasil belajar peserta didik antara lain, faktor internal dan faktor ekstern. Faktor internal ialah faktor yang berasal dari dalam diri siswa sendiri meliputi tiga faktor, yakni: faktor jasmaniah, factor psikologis, dan kesiapan. Sedangkan faktor ekstern ialah faktor yang berasal dari luar diri siswa sendiri, yang terdiri dari tiga faktor, yakni faktor keluarga, faktor sekolah.

\section{Pembelajaran Bahasa Arab}

Mata pelajaran Bahasa Arab merupakan suatu mata pelajaran yang diarahkan untuk mendorong, membimbing, mengembangkan dan membina kemampuan serta menumbuhkan sikap positif terhadap Bahasa Arab baik reseptif maupun produktif. Kemampuan reseptif yaitu kemampuan untuk memahami pembicaraan orang lain dan memahami bacaan. Kemampuan produktif yaitu kemampuan menggunakan bahasa sebagai alat komunikasi baik secara lisan maupun secara tertulis. Kemampuan berbahasa Arab serta sikap positif terhadap Bahasa Arab tersebut sangat penting dalam membantu memahami sumber ajaran Islam yaitu alQur'an dan Hadis, serta kitab-kitab berbahasa Arab yang berkenaan dengan Islam bagi peserta didik. ${ }^{16}$

Bahasa Arab, sebagaimana bahasabahasa yang lain memiliki empat keterampilan bahasa (maharot al-lughoh). Dengan menggunakan kata maharoh, dapat dipahami bahwa aspek yang paling mendasar dari bahasa itu adalah alat komunikasi, dan keterampilan adalah bagian yang paling mendasar ketika menggunakan bahasa. Keempat maharoh itu adalah, pertama maharoh al-istima' (keterampilan mendengar), kedua maharoh alkalam (keterampilan berbicara), ketiga maharoh al-qiro'ah (keterampilan membaca) dan keempat maharoh alkitabah (keterampilan menulis). ${ }^{17}$

Hal prinsip dalam pengajaran bahasa adalah, bahwa pengajaran bahasa harus dimulai dengan mengajarkan aspekaspek pendengaran dan pengucapan sebelum aspek-aspek membaca dan menulis. Dengan demikian menyimak

16 Kepala Kementerian Agama RI, Peraturan Menteri Agama RI Nomor 2 Tahun 2008, (Kemenag RI, Jakarta, 2008), h. 52.

17 Imam Makruf, Strategi Pembelajaran Bahasa Arab Aktif, (Semarang: Need's Press, 2009), h. 18. 
merupakan satu pengalaman belajar yang amat penting bagi para peserta didik.

Keterampilan berbicara pada dasarnya adalah menyangkut kemampuan berkomunikasi dua arah antara pembicara dengan pendengarnya. Kemampuan berbicara tidak dapat dilepaskan dari kemampuan menyimak. Kemampuan berbicara didasari oleh kemampuan mendengarkan (reseptif), kemampuan mengucapkan (produktif) dan pengetahuan (relative) kosa-kata dan pola kalimat yang memungkinkan peserta didik dapat mengkomunikasikan maksud/fikirannya.

Adapun keterampilan membaca mencakup dua hal, pertama mengubah lambang tulis menjadi bunyi dan kedua menangkap arti dari seluruh situasi yang dilambangkan dengan lambang-lambang tulis dan bunyi tersebut. $^{18}$ Membaca dengan suara keras merupakan tahap awal yang harus dikuasai terlebih dahulu oleh seseorang sebelum berlatih membaca tanpa bersuara. Hal ini dikarenakan membaca dengan bersuara dapat melatih cara mengucapkan Bahasa Arab dengan benar. ${ }^{19}$

Keterampilan menulis secara umum dimaksudkan untuk berkomunikasi secara tertulis. Kitabah pada dasarnya merupakan ungkapan dari apa yang

${ }^{18}$ Abdul Mu'in, Analisis Kontrastif Bahasa Arab dan Bahasa Indonesia; ( Jakarta: Pustaka Al Husna Baru, 2004), h. 170.

${ }^{19}$ Imam Makruf, Strategi Pembelajaran..., h. 26 . dipikirkan kepada orang lain dalam bentuk tulisan. Keterampilan ini secara umum juga mempunyai dua aspek, yaitu kemahiran membentuk alphabet dan mengeja, serta kemahiran melahirkan pikiran dan perasaan dengan tulisan. ${ }^{20}$

Mata pelajaran Bahasa Arab mempunyai tujuan sebagai berikut :

a. Mengembangkan kemampuan berkomunikasi dalam Bahasa Arab, baik lisan maupun tulis, yang mencakup empat kecakapan berbahasa, yakni menyimak, berbicara, membaca dan menulis.

b. Menumbuhkan kesadaran tentang pentingnya Bahasa Arab sebagai salah satu bahasa asing untuk menjadi alat utama belajar, khususnya dalam mengkaji sumbersumber ajaran Islam.

c. Mengembangkan pemahaman tentang saling keterkaitan antara bahasa dan budaya serta memperluas cakrawala budaya. Dengan demikian peserta didik diharapkan memiliki wawasan lintas budaya dan melibatkan diri dalam keragaman budaya. ${ }^{21}$

Adapun ruang lingkup pelajaran Bahasa Arab di Madrasah Tsanawiyah meliputi tema-tema yang berupa wacana 
lisan dan tulisan berbentuk paparan atau dialog sederhana tentang identitas diri, kehidupan madrasah, kehidupan keluarga, rumah, hobi, profesi, kegiatan keagamaan dan lingkungan

Prinsip-prinsip pembelajaran

Bahasa Arab pada hakekatnya sama dengan prinsip-prinsip pembelajaran bahasa asing yang lain. Hal ini dikarenakan masing-masing bahasa memiliki kesamaan. Imam makruf mengutip pendapat Kamal Ibrahim Badri dan Mamduh Nuruddin, menyebutkan adanya 5 prinsip dalam pembelajaran bahasa asing, yaitu:

a. Prioritas atau mendahulukan yang lebih utama, yaitu istima' dan kalam terlebih dahulu kemudian kitabah, mengajarkan jumlah sebelum kalimat, mengajarkan mufrodat yang fungsional dan diajarkan dengan kecapatan yang biasa digunakan pemilik bahasa aslinya.

b. Ketepatan. Pembelajaran bahasa harus memperhatikan aspek ketepatan dalam hal bunyi (cara mengucapkan), struktur kalimat dan sesuai dengan konteksnya.

c. Tahapan. Dimulai dari yang maklum (diketahui) kemudian yang majhul (belum diketahui), dari yang global sampai yang terperinci dan setiap tahapan merupakan landasan bagi tahapan berikutnya dan dapat memberikan pengembangan dalam belajar.

d. Aspek motivasi, yaitu menjauhkan hal-hal yang mendatangkan keraguraguan, memberikan dorongan, membangkitkan rasa kebersamaan, memasukkan unsur bermain dalam latihan dan membangun hubungan yang baik.

e. Baku dan mendasar, belajar bahasa dengan cara menggunakannya bukan menjelaskan kaidahnya, menvisualisasikan sedapat mungkin dengan contoh-contoh dan mengulang-ulang dengan sebanyakbanyak contoh. ${ }^{22}$

Tujuan utama dari pembelajaran Bahasa Arab adalah menggali dan mengembangkan kemampuan peserta didik dalam menggunakan bahasa, baik secara aktif (lisan) ataupun pasif (tulis). Dalam dunia pembelajaran bahasa, kemampuan menggunakan bahasa disebut "kemahiran berbahasa" (maharah al-lughah). Pada umumnya, semua pakar pembelajaran bahasa sepakat bahwa keterampilan dan kemahiran berbahasa tersebut terbagi empat. Di antaranya adalah keterampilan menyimak (maharah al-istima'), keterampilan berbicara (maharah alkalam), keterampilan membaca (maharah

${ }^{22}$ Imam Makruf, Strategi Pembelajaran ...., h. 42. 
alqira'ah), dan keterampilan menulis (maharah al-kitabah). Adapun keterampilan menyimak dan membaca dikategorikan dalam keterampilan berbahasa reseptif. Sedangkan keterampilan berbicara dan menulis dikategorikan dalam keterampilan bahasa produktif. $^{23}$

Keterampilan Menyimak (Maharah al-Istima'/listening skill) adalah kemampuan seseorang dalam mencerna dan memahami kata atau kalimat yang diujarkan oleh mitra bicara atau media tertentu. ${ }^{24}$ Maharah al-istima', atau sering juga disebut keterampilan menyimak, terdapat pada setiap tujuan pembelajaran bahasa, baik bahasa pertama atau kedua.

Keterampilan menyimak baru diakui sebagai komponen utama dalam berbahasa pada tahun 1970-an dengan munculnya teori total physical response (TPS) dari James Asher, the natural approach, dan silent period-nya. Teoriteori tersebut menyatakan bahwa menyimak bukanlah kegiatan satu $\operatorname{arah}^{25}$ karena kegiatan tersebut diikuti oleh respon-respon fisik (meraih, meraba, bergerak, melihat, dan seterusnya). Keterampilan menyimak (dan membaca)

23 Ulin Nuha, Metodologi Super Efektif Pembelajaran Bahasa Arab, (Cet. I; Jogjakarta: Diva Press, 2012), h. 83.

24 Acep Hermawan, Metodologi Pembelajaran Bahasa Arab (Bandung: Remaja Rosdakarya, 2011), h. 130.

25 Iskandarwassid dan dadang Sunendar, Strategi Pembelajaran Bahasa (Bandung: Remaja Rosdakarya, 2008), h. 227. termasuk dalam kemampuan pemahaman, atau disebut juga dengan keterampilan reseptif. $^{26}$

Menurut Acep Hermawan, keterampilan berbicara (Maharah alKalam) adalah kemampuan mengungkapkan bunyi-bunyi artikulasi atau kata-kata untuk mengekspresikan pikiran berupa ide, pendapat, keinginan atau perasaan kepada mitra bicara. ${ }^{27}$ Dalam makna yang lebih luas, berbicara merupakan suatu sistem tanda-tanda yang dapat didengar dan dilihat, yang memanfaatkan sejumlah otot dan jaringan otot tubuh manusia. Tujuannya adalah untuk menyampaikan pikiran dalam rangka memenuhi kebutuhannya. Sedangkan, menurut Henri Guntur Tarigan, berbicara merupakan kombinasi faktor-faktor fisik, psikologi, neurologis, semantik, dan linguistik secara luas. Sehingga, dapat dianggap sebagai alat manusia yang paling penting bagi kontrol sosial. ${ }^{28}$

Membaca adalah kemampuan mengenali dan memahami isi sesuatu yang tertulis) dengan melafalkan atau mencernanya di dalam hati. Pada hakikatnya, membaca adalah proses komunikasi antara pembaca dengan

26 Sri Utari Subyakto-Nababan, Metodologi Pengajaran Bahasa (Jakarta: Gramedia Pustaka Utama, 1993), h. 150.

27 Acep Hermawan, Metodologi Pembelajaran..., h. 135.

28 Henri Guntur Tarigan, Berbicara sebagai Suatu Keterampilan Berbahasa (Bandung: Angkasa, 1994), h. 15. 
penulis melalui teks yang ditulisnya. Maka, secara langsung, di dalamnya terjadi hubungan kognitif antara bahasa lisan dan tulisan. Tarigan berpendapat bahwa membaca adalah proses yang dilakukan dan dipergunakan oleh pembaca untuk memperoleh pesan yang hendak disampaikan oleh penulis melalui media kata-kata atau bahasa tulis. ${ }^{29}$

Membaca merupakan kegiatan untuk mendapatkan makna dari yang tertulis dalam teks. Untuk keperluan tersebut, selain harus menguasai bahasa yang dipergunakan, seorang pembaca perlu juga mengaktifkan berbagai proses mental dalam sistem kognisinya. ${ }^{30}$

Kemahiran membaca mencakup dua hal, yaitu mengenali simbol-simbol yang tertulis dan memahami isinya. Bagi para peserta didik Indonesia yang mempunyai latar belakang kemahiran membaca tulisan Latin, kemahiran membaca tulisan Arab merupakan masalah. Sebab, alphabet Arab berlainan dengan alphabet Latin. Alphabet Arab mempunyai sistem dan karakteristik tersendiri. $^{31}$

Kemampuan membaca Bahasa Arab sangat tergantung kepada pemahaman isi atau arti yang dibaca. Ini

\footnotetext{
${ }^{29}$ Ibid, h. 7.

30 Iskandarwassid dan Dadang Sunendar, Strategi Pembelajaran ..., h. 246.

31 A. Akrom Malibary, dkk, Pedoman Pengajaran Bahasa Arab pada Perguruan Tinggi Agama/IAIN (Depag R.I., 1976), h. 168.
}

berarti sangat tergantung pada penguasaan Qawaid atau gramatika Bahasa Arab yang meliputi nahwu dan saraf (sintaktis dan morfologi). Oleh karena itu, kemahiran membaca dalam Bahasa Arab setelah memahami, bukan membaca untuk memahami. Artinya, memahami terlebih dahulu gramatika Bahasa Arab, baru bisa membaca dengan benar. ${ }^{32}$ Oleh karena itu, pengajaran membaca perlu memperoleh perhatian serius dan wacana membaca tidak boleh hanya dipandang sebagai batu loncatan bagi aktivitas berbicara dan menulis semata. Tujuan pengajaran membaca adalah mengembangkan kemampuan membaca peserts didik. Dengan demikian, tugas guru adalah meyakinkan proses pembelajaran membaca menjadi pengalaman yang menyenangkan bagi peserta didik. ${ }^{33}$

Keterampilan menulis adalah kemampuan dalam mendeskripsikan atau mengungkapkan isi pikiran, mulai dari aspek yang paling sederhana, seperti menulis kata-kata, sampai kepada aspek yang kompleks, yaitu mengarang. ${ }^{34}$ Keterampilan menulis merupakan keterampilan yang sangat dibutuhkan pada masa sekarang. Keterampilan ini menjadi salah satu cara untuk pengungkapan

${ }^{32}$ Ibid., h. 169.

33 Furqanul Azies dan A. Chaidar alWasilah, Pengajaran Bahasa Komunikatif, Teori dan Praktik (Bandung: Remaja Rosdakarya, 1996), h. 108.

${ }^{34}$ Acep Hermawan, Metodologi

Pembelajaran..., h. 151. 
pemikiran, perasaan, harapan, cita-cita atau segala sesuatu yang dipikirkan dan dirasakan oleh manusia.

Keterampilan menulis menjadi sangat penting artinya dalam pelestarian, penyebaran, dan pengembangan ilmu pengetahuan. Suatu penemuan baik berupa ide-ide, syair, dongeng, cerita maupun teknik-teknik tertentu akan mudah hilang jika tidak dicatat. Hal ini disebabkan oleh terbatasnya daya ingat manusia.

Dalam konteks pembelajaran bahasa, utamanya Bahasa Arab, keterampilan menulis (maharah alkitabah) dibagi menjadi tiga, yaitu kaligrafi, imla', dan mengarang.

\section{Metode Penelitian}

Penelitian ini dilaksanakan di Madrasah Tsanawiyah Negeri Model Palu. Populasi dalam penelitian ini adalah keseluruhan peserta didik yang belajar Bahasa Arab di Madrasah Tsanawiyah Negeri Model Palu. Jumlah sampel dalam penelitian ini adalah 90 orang peserta didik yang belajar bahasa Arab di Madrasah Tsanawiyah Negeri Model Palu. Adapun teknik pengambilan sampel yang digunakan ialah probability sampling. Probabilty sampling adalah teknik sampling yang memungkinkan seluruh populasi mempunyai peluang yang sama untuk menjadi sampel. Dan untuk teknik pengambilan sampel, peneliti menggunakan teknik random sampling merujuk pada teori Slovin menurut Taro Yamani sebagai berikut:

$$
\mathrm{n}=\frac{\mathrm{N}}{1+\mathrm{Ne}^{2}} \quad 35
$$

Dimana :

$$
\begin{array}{rlr}
\mathrm{n}= & \text { Ukuran Sampel } & \\
\mathrm{N}= & \text { Ukuran Populasi } & \\
\mathrm{e} & =\text { Persen } & \text { kelonggaran } \\
& \text { ketidaktelitian } & \text { karena } \\
& \text { kesalahan } & \text { pengambilan } \\
& \text { sampel yang } & \text { masih dapat } \\
& \text { ditoleransi } &
\end{array}
$$

Pengambilan data dari seluruh peseta didik tersebut menggunakan kuesioner. Adapun kisi-kisi instrumen ini adalah pernyataan yang berhubungan dengan variabel Profesionalisme Guru dan pernyataan yang berhubungan dengan variabel hasil belajar peserta didik pada mata pelajaran Bahasa Arab.

\section{Hasil dan Pembahasan}

Data yang diperoleh dari penyebaran skala, yang kemudian diolah dan dianalisis, sehingga data-data penelitian tersebut dapat disajikan sebagai berikut.

Hasil analisis regresi linear sederhana diperoleh intisari hasil penelitian dari tanggapan 90 responden sehubungan dengan pengaruh dari variabel independen yaitu profesionalisme guru terhadap hasil

35 Haryadi Sarjono, SPSS vs LISREL (Sebuah Pengantar Untuk Riset), (Jakarta: Salemba Empat, 2011), h. 30. 
belajar peserta didik di Madrasah Tsanawiyah Negeri Model Palu. Dengan rincian yang diformulasikan dalam tabel XIII sebagai berikut:

\section{TABEL I}

\section{Hasil Perhitungan Regresi Linear}

\section{Sederhana}

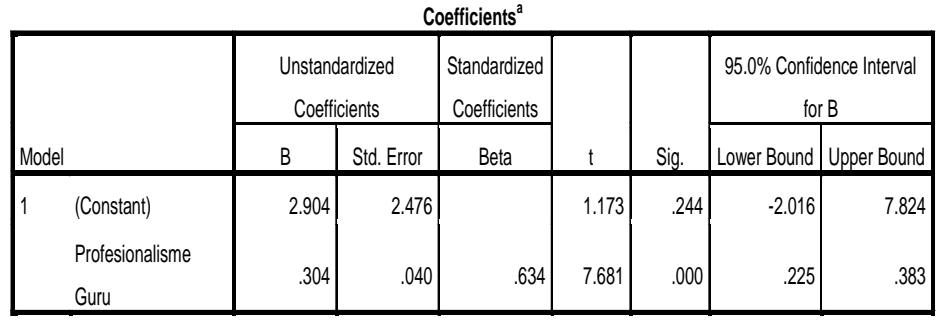

a. Dependent Variable: Hasil Belajar Peserta didik

$$
\begin{array}{ll}
\text { Konstanta } & =2.904 \\
\text { f-hitung } & =58.996 \\
\text { R } & =0.634 \\
\text { Sig.f } & =0.000 \\
\text { R.Square } & =0.401 \\
\alpha & =0.05
\end{array}
$$

\section{Berdasarkan hasil perhitungan}

tersebut di atas, persamaan regresi yang dibangun dengan menggunakan nilai nilai yang diperlukan sebagai berikut :

$$
Y=2.904+0.304 X
$$

Persamaan tersebut menunjukan, bahwa variabel independen yang dianalisis (X1) memberikan pengaruh positif dan signifikan terhadap hasil belajar peserta didik di Madrasah Tsanawiyah Negeri Model Palu. Nilai konstanta seperti yang ditunjukkan dalam Tabel XII di atas sebesar 1.625. Besarnya keterkaitan (hubungan) antara variable $\mathrm{X}$ terhadap hasil belajar peserta didik terlihat pada nilai $\mathrm{R}$ sebesar 0.634. Jika ditafsirkan nilai tersebut maka dapat dikatakan bahwa terjadi hubungan antara variabel independen terhadap variabel dependen dengan nilai hubungan sebesar $63.4 \%$, sehingga variabel independen tersebut layak untuk diteliti.

Pengujian hipotesis pertama adalah untuk mengetahui apakah variabel profesionalisme guru berpengaruh signifikan terhadap hasil belajar peserta didik di Madrasah Tsanawiyah Negeri Model Palu. Hal ini akan digambaran pada

\begin{tabular}{|c|c|c|c|c|c|c|}
\hline \multicolumn{7}{|c|}{ ANOVA $^{a}$} \\
\hline \multicolumn{2}{|c|}{ Model } & Sum of Squares & $d f$ & Mean Square & $\mathrm{F}$ & Sig. \\
\hline 1 & Regression & 145.148 & 1 & 145.148 & 58.996 & $.000^{b}$ \\
\hline & Residual & 216.507 & 88 & 2.460 & & \\
\hline & Total & 361.656 & 89 & & & \\
\hline
\end{tabular}
tabel yang diperoleh dari hasil olahan data melalui program komputer SPSS22. Untuk lebih jelasnya dapat dilihat pada tabel di bawah ini:

\section{TABELII}

\section{Pengujian Hipotesis}

a. Dependent Variable: Hasil Belajar Peserta didik

b. Predictors: (Constant), Profesionalisme Guru

Dari tabel di atas, dapat diketahui bahwa nilai signifikan probabilitasnya adalah 0.000. Artinya bahwa jika nilai probabilitas f-hitung $<\alpha(0.05)$, maka hipotesis mula - mula ( Ho ) yang menyatakan bahwa tidak terdapat pengaruh 
signifikan antara variabel profesionalisme guru terhadap variabel hasil belajar peserta didik ditolak. Sebaliknya hipotesis alternatif ( $\mathrm{Ha}$ ) yang menyatakan bahwa terdapat pengaruh yang signifikan antara variabel independen terhadap variabel dependen diterima, atau dengan kata lain terdapat pengaruh signifikan antara variabel profesionalisme guru terhadap variabel hasil belajar peserta didik pada mata pelajaran Bahasa Arab di Madrasah Tsanawiyah Negeri Model Palu.

Untuk mengetahui seberapa besar tingkat pengaruh profesionalisme guru terhadap hasil belajar peserta didik pada mata pelajaran Bahasa Arab di Madrasah Tsanawiyah Negeri Model Palu dapat diketahui pada tabel XIV berikut ini:

TABEL III

Tingkat Pengaruh Profesionalisme

Guru terhadap Hasil Belajar

Peserta Didik pada Mata Pelajaran

Bahasa Arab

di Madrasah Tsanawiyah Negeri Model

Palu

Model Summary

\begin{tabular}{|l|c|r|r|c|}
\hline Model & \multicolumn{1}{|c|}{$\mathrm{R}$} & $\mathrm{R}$ Square & \multicolumn{1}{c|}{$\begin{array}{c}\text { Adjusted R } \\
\text { Square }\end{array}$} & $\begin{array}{c}\text { Std. Error of the } \\
\text { Estimate }\end{array}$ \\
\hline 1 & $.634^{\mathrm{a}}$ & .401 & .395 & 1.569 \\
\hline
\end{tabular}

a. Predictors: (Constant), Profesionalisme Guru

Presentase pengaruh variabel independen terhadap nilai variabel dependen ditunjukkan oleh besarnya koefisien determinasi ( $R$ Square). Pada hasil perhitungan diperoleh besarnya koefisien determinasi ( $R$ Square) adalah 0.634. Nilai ( $R$ Square) sebesar 0.401 jika kita merubahnya menjadi persen $(\%)$ maka menjadi $0.401 \times 100=40.1 \%$.

Artinya bahwa sebesar $40.1 \%$ tingkat perubahan variabel hasil belajar peserta didik pada mata pelajaran Bahasa Arab di Madrasah Tsanawiyah Negeri Model Palu dipengaruhi oleh variabel profesionalisme guru, sedangkan sisanya sebesar $59.9 \%$ dipengaruhi faktor - faktor lain yang tidak dimasukkan dalam penelitian ini.

\section{Kesimpulan}

Dari uraian tersebut dapat disimpulkan bahwa hasil belajar peserta didik pada mata pelajaran bahasa Arab sangat dipengaruhi oleh profesionalisme guru. Dengan adanya guru yang memiliki profesionalisme yang tinggi dapat memberikan pengaruh yang signifikan terhadap hasil belajar peserta didik. Meskipun dalam penelitian ini menunjukkan bahwa kompetensi profesional guru berpengaruh terhadap hasil belajar peserta didik dengan persentase yang cukup baik, akan tetapi bukan berarti guru bidang studi maupun peserta didik merasa puas dengan situasi yang ada. Penulis mengharapkan bagi guru bidang studi agar lebih meningkatkan kompetensi profesional khususnya 
kemampuan guru dalam melaksanakan dan mengelola proses belajar mengajar, menguasi materi lebih mendalam dan menguasai serta harus lebih inovatif dan kreatif dalam menggunakan model dan metode pembelajaran yang ada. Sedangkan bagi peserta didik yang nilainya belum tuntas diharapkan lebih giat lagi belajar demi meningkatkan hasil belajar agar mencapai standar ketuntasan yang ditetapkan, dan untuk peserta didik yang sudah tuntas dalam mata pelajaran Bahasa Arab diharapkan mampu mempertahankan dan lebih meningkatkan nilainya tersebut, kemudian terus menggali berbagai macam potensi dan kemampuan yang ada pada diri sehingga hasil pembelajaran akan lebih maksimal. Selanjutnya, meskipun hasil belajar peserta didik dapat dikualifikasikan cukup baik, akan tetapi peserta didik diharapkan lebih meningkatkan hasil belajar baik secara konseptual maupun praktis. Karena khusus dalam mata pelajaran bahasa Arab, penguasaan peserta didik tidak hanya terbatas kepada penguasaan konsep, melainkan peserta didik harus mampu mengimplementasikannya dalam kehidupan sehari-hari agar wawasan peserta didik selalu berkembang sesuai dengan ilmu yang didapatnya. Dengan demikian, apabila hal tersebut dapat dilaksanakan dengan baik, maka tujuan hasil belajar akan lebih optimal.

\section{Daftar Pustaka}

Azies, Furqanul dan A. Chaidar alWasilah. (1996). Pengajaran Bahasa Komunikatif, Teori dan Praktik. Bandung: Remaja Rosdakarya.

B. Uno, Hamzah. (2012). Profesi Kependidikan. Jakarta: PT Bumi Aksara.

Danim, Sudarwan. (2013). Profesionalisasi dan Etika Profesi Guru. Bandung: Alfabeta.

Echols, John M dan Hasan Shadily. (1990). Kamus Inggris Indonesia. Jakarta: Gramedia.

Getteng, Abd. Rahman. (2011). Menuju Guru Profesional dan Beretika. Yogyakarta: Graha Guru.

Hermawan, Acep. (2011). Metodologi Pembelajaran Bahasa Arab. Bandung: Remaja Rosdakarya.

Iskandarwassid dan Dadang Sunendar, (2008). Strategi Pembelajaran Bahasa. Bandung: Remaja Rosdakarya.

Kepala Kementerian Agama RI. (2008). Peraturan Menteri Agama RI Nomor 2 Tahun 2008. Jakarta: Kemenag RI.

Kusnandar. (2007). Guru Profesional Implementasi Kurikulum Tingkat Satuan Pendidikan (KTSP) dan Persiapan Menghadapi Sertifikasi Guru. Jakarta: PT Raja Grafindo Persada.

Makruf, Imam. (2009). Strategi Pembelajaran Bahasa Arab Aktif. Semarang: Need's Press.

Malibary, A. Akrom, dkk. (1976). Pedoman Pengajaran Bahasa Arab pada Perguruan Tinggi Agama/IAIN. Depag R.I 
Mudlofir, Ali. (2012). Pendidik Profesional. Jakarta: PT Raja Grafindo Persada.

Mu'in, Abdul. (2004). Analisis Kontrastif Bahasa Arab dan Bahasa Indonesia. Jakarta: Pustaka Al Husna Baru.

Nuha, Ulin. (2012). Metodologi Super Efektif Pembelajaran Bahasa Arab. Cet. I; Jogjakarta: Diva Press.

Oemar, Hamalik. 1990. Metode Belajar dan Kesulitan-kesulitan Belajar. Bandung: Tarsito.

Pusat Bahasa Depdiknas. (2001). Kamus Besar Bahasa Indonesia edisi III. Cet. I; Jakarta: Balai Pustaka.

Sardiman. 2002. Media Pendidikan. Jakarta: Raja Grafindo Persada.

Sarjono, Haryadi. 2011. SPSS vs LISREL (Sebuah Pengantar Untuk Riset), Jakarta: Salemba Empat.
Slameto. 2003. Belajar dan Faktor-Faktor yang mempengaruhinya. Jakarta: Rineka Cipta.

Subyakto-Nababan, Sri Utari. (1993). Metodologi Pengajaran Bahasa. Jakarta: Gramedia Pustaka Utama.

Sudjana, Nana. (1991). Penilaian Hasil Proses Belajar Mengajar. Bandung: PT Remaja Rosdakarya Taniredja, Tukiran dan Mustafidah, Hidayati. (2014). Penelitian Kuantitatif (Sebuah Pengantar). Bandung: Alfabeta.

Sudjana, Nana. (1991). Penilaian Hasil Proses Belajar Mengajar. Bandung: PT Remaja Rosdakarya Taniredja, Tukiran dan Mustafidah, Hidayati. (2014). Penelitian Kuantitatif (Sebuah Pengantar). Bandung: Alfabeta.

Yunus, Abu Bakar dan Syarifan Nurjan. (2009). Profesi Keguruan. Surabaya: A Print. 